\title{
Федір ТКАЧИК
}

кандидат економічних наук, доцент, Тернопільський національний економічний університет, Тернопіль, Україна, tkachyk.fp@gmail.com

ORCID ID: 0000-0002-4783-6919

\section{Вікторія ОСТАПЧУК}

кандидат економічних наук, заступник міського голови з питань діяльності виконавчих органів ради, Тернопільська міська рада, Тернопіль, Україна, viktoriaostp@gmail.com

ORCID ID: 0000-0003-1144-8822

\section{ЄВРОПЕЙСЬКІ ПРІОРИТЕТИ ОПОДАТКУВАННЯ ДОХОДІВ ФІЗИЧНИХ ОСІБ}

Вступ. В сучасних умовах глобалізації соціально-економічного розвитку та фрормування нової фрінансової цивілізації визначне місце посідають суспільні аспекти податкової політики. Система оподаткування доходів громадян в Україні сьогодні не повною мірою може впоратися із виконанням своїх фрункцій. Досвід розвинених європейських країн щодо фрормування ефективного механізму оподаткування доходів фрізичних осіб сприятиме налагодженню новітньої соціальної та фіскально-орієнтованої парадигми оподаткування громадян в Україні. Посилення інтересу до процедур адміністрування податку на доходи фрізичних осіб також пояснюється тим, що цей податок є одним із основних джерел надходження до бюджету України.

Мета - визначити особливості справляння податку на доходи фрізичних осіб в Україні, з'ясувати спільне та відмінне у системі оподаткування в Україні та європейських країнах, систематизувати рекомендації щодо вдосконалення механізму оподаткування доходів громадян.

Результати. Наведено типологізацію систем оподаткування доходів фрізичних осіб у зарубіжних країнах. Розглянуто загальні риси оподаткування доходів громадян та механізми застосування ставок податку на доходи фрізичних осіб в деяких країнах Європейського Союзу. Аргументовано, що імплементація європейського податкового досвіду сприятиме швидшому переходу до нової та дієвої системи оподаткування доходів фрізичних осіб в Україні. Для вдосконалення оподаткування доходів фрізичних осіб в Україні необхідно переглянути ставки податку на доходи фрізичних осіб, збільшити розмір неоподатковуваного мінімуму доходів громадян, забезпечити повноцінне фрункіонування електронного декларування доходів громадян, оптимізувати пільгову політику, підвищити рівень податкової грамотності та податкової культури населення тощо.

Перспективи. У подальших наукових дослідженнях увагу буде приділено соціальним аспектам оподаткування доходів громадян в частині диференціації податкових ставок, логічності використання префреренцій в оподаткуванні доходів фрізичних осіб, запровадження дієвого порогу неоподатковуваного мінімуму доходів громадян, популяризації права на податкові знижки тощо.

() Федір Петрович Ткачик, Вікторія Олександрівна Остапчук, 2020 
Ключові слова: фріскальна політика, податкова система, прямі податки, податок на доходи фрізичних осіб, елементи податку, податкова політика ЄС, податкова культура.

Рис.: 1, табл.: 2, бібл.: 15.

\section{Федор ТКАЧЫК}

кандидат экономических наук, доцент, Тернопольский национальный экономический университет, Тернополь, Украина

\section{Виктория ОСТАПЧУК}

кандидат экономических наук, Тернопольский городской совет, Тернополь, Украина

\section{ЕВРОПЕЙСКИЕ ПРИОРИТЕТЫ НАЯОГООБАОЖЕНИЯ ДОХОДОВ ФИЗН- ЧЕСКИХ АНЦ}

Введение. В современных условиях глобализации социально-экономического развития и формирования новой финансовой цивилизации выдающееся место занимают общественные аспекты налоговой политики. Система налогообложения доходов граждан в Украине сегодня не в полной мере справляется с выполнением своих функций. Опыт европейских стран по фрормированию эфрфективного механизма налогообложения доходов фризических лиц будет способствовать налаживанию новой социальной и фискально-ориентированной парадигмы налогообложения граждан в Украине. Повышение интереса к процедурам администрирования налога на доходы фризических лиц также объясняется тем, что данный налог является одним из основных источников поступления в бюджет Украины.

Цель - определение особенностей взимания налога на доходы фризических лиц в Украине, выяснение общего и отличного в системе налогообложения в Украине и европейских странах, систематизация рекомендаций по совершенствованию механизма налогообложения доходов граждан.

Результаты. Освещено типологизацию систем налогообложения доходов физических лиц в зарубежных странах. Рассмотрены общие черты налогообложения доходов граждан и механизмы применения ставок налога на доходы фризических лиц в некоторых странах Европейского Союза. Аргументировано, что имплементация европейского налогового опыта будет способствовать более быстрому переходу к новой и эфрфективной системе налогообложения доходов физических лиц в Украине. Для совершенствования налогообложения доходов физических лиц в Украине необходимо пересмотреть ставки налога на доходы фризических лиц, увеличить размер необлагаемого минимума доходов граждан, обеспечить полноценное фрунционирование электронного декларирования доходов граждан, оптимизировать льготную политику, повысить уровень налоговой грамотности и налоговой культуры населения и тому подобное.

Перспективы. В дальнейших научных исследованиях внимание будет уделено социальным аспектам налогообложения доходов граждан в части диффреренциации налоговых ставок, логичности использования преференций в налогообложении доходов фризических лиц, введения действенного порога необлагаемого минимума доходов граждан, популяризации права на налоговые скидки и тому подобное.

Ключевые слова: фискальная политика, налоговая система, прямые налоги, налог на доходы фризических лиц, элементы налога, налоговая политика EC, налоговая культура. 


\section{Fedir TKACHYK}

Ph. D. (Economics), Assoc. Prof., Ternopil National Economic University, Ternopil, Ukraine, tkachyk.fp@gmail.com

ORCID ID: 0000-0002-4783-6919

\section{Victoriia OSTAPCHUK}

Ph. D. (Economics), Ternopil city council, Ternopil, Ukraine, viktoriaostp@gmail.com ORCID ID: 0000-0003-1144-8822

\section{EUROPEAN PRIORITIES FOR PERSONAL INCOME TAXATION}

Introduction. In the current conditions of globalization of socio-economic development and formation of a new financial civilization, social aspects of tax policy take a important place. The system of taxation of income of citizens in Ukraine today is not fully coping with the performance of their functions. The experience of developed European countries on the formation of an effective mechanism of taxation of personal income will contribute to the establishment of the newest social and fiscal-oriented paradigm of taxation of citizens in Ukraine. The increased interest in the procedures for administering the personal income tax is also explained by the fact that this tax is one of the main sources of income to the budget of Ukraine.

The purpose is to determine the peculiarities of taxation of personal income tax in Ukraine, to find out the common and different features tax system in Ukraine and European countries, to systematize recommendations on improving the mechanism of taxation of personal income.

Results. The international typology of personal income tax systems is given. The general features of personal income taxation and mechanisms of application of personal income tax rates in some countries of the European Union are considered. It is argued that the implementation of the European tax experience will facilitate a faster transition to a new and effective system of personal income taxation in Ukraine. To improve personal income taxation in Ukraine, it is necessary to revise personal income tax rates, increase the amount of tax-free minimum incomes, ensure the full functioning of electronic declaration of personal incomes, optimize concessional policies, increase tax literacy and tax culture.

Prospects. Further research will focus on the social aspects of taxing citizens' income in terms of differentiation of tax rates, the logic of using preferences in taxing personal income, the introduction of an effective threshold of the non-taxable minimum income, promoting the right to tax rebates, etc.

Keywords: fiscal policy, tax system, direct taxes, personal income tax, elements of tax, EU tax policy, tax culture.

JEL Classification: E63, H24, H71.

Постановка проблеми. Побудова адаптованої до реальних умов розвитку кожної держави системи оподаткування доходів фізичних осіб має важливе значення, адже вона $є$ однією з найбільш пріоритетних і впливових у контексті наповнення бюджетних ресурсів; група платників податку на доходи фрізичних осіб є найчи- сельнішою, а постулати соціальної справедливості в оподаткуванні частіше проявляються в механізмах адміністрування податку на доходи фрізичних осіб.

Пріоритетним напрямом модернізації системи оподаткування в Україні $є$ вдосконалення адміністрування податків, зокрема податку на доходи фрізичних осіб. Мета 
такого вдосконалення полягає у створенні більш ефективного механізму адміністрування подоходного податку з громадян, недопущенні проявів корупції у податкових відносинах, сприянні підвищенню добровільності сплати податку, формуванні партнерських взаємовідносин між фіскальними органами та платниками податків, створенні справедливих умов оподаткування для всіх платників та забезпеченні надходження податку на доходи фрізичних осіб до бюджетів усіх рівнів у повному обсязі. Для успішного досягнення цієї мети актуальним $є$ врахування провідного європейського досвіду та його адаптація до українських умов.

Аналіз останніх досліджень і публікацій. Науково-методологічну основу дослідження механізмів адміністрування податку на доходи фрізичних осіб в українській та зарубіжній фріскальній практиці становлять праці таких науковців та фрахівців: Н. Абрамченко [13], О. Десятнюк [12], Н. Дутової [3], Л. Духновської [1], А. Карповіча [10], А. Крисоватого [15], О. Крівцова [7], О. Круковської [14], О. Куби [6], Н. Танклевської [5], Ю. Швець [4] та ін.

Але, враховуючи останні виклики суспільства та фрінансову політику держави, спрямовану на децентралізацію управління, в напрямку передачі влади територіальним громадам, в бюджетах яких податок на доходи фрізичних осіб становить більшу частку надходжень, виникає необхідність пошуку нових фрінансових інструментів ефективного адміністрування податку на доходи фрізичних осіб в Україні.

Мета статті полягає в науково-методичному обґрунтуванні актуальних аспектів оподаткування доходів громадян в європейському фріскальному просторі та систематизації пріоритетів удосконалення процедур оподаткування доходів фрізичних осіб в Україні.
Виклад основного матеріалу дослідження. У багатьох зарубіжних країнах вирізняють певні спільні риси при побудові системи адміністрування подоходного податку з громадян, проте кожна держава має свої особливості. Будь-яка країна світу обирає власні методичні підходи для здійснення оподаткування доходів фрізичних осіб, це може залежати від соціальних стандартів і стратегії розвитку держави, однак визначальною ознакою такого оподаткування $€$ те, що воно має сприяти зростанню заощаджень населення країни, які в подальшому слугують одним із джерел фрінансування економіки. Важливим завданням для будь-якої держави $є$ постійне удосконалення системи оподаткування доходів фрізичних осіб з метою забезпечення іï соціальної справедливості, фріскальної та економічної ефрективності. Виокремлюють кілька типів систем оподаткування доходів фізичних осіб, які фрункціонують у різних країнах світу (рис. 1).

Кожна країна, враховуючи вищезазначені типи систем оподаткування та їх особливості, формує індивідуальну систему оподаткування доходів громадян з визначеними законодавством об'єктом, базою оподаткування, системою податкових пільг і ставок. У будь-якій державі податкова система побудована з урахуванням специфіки організації її господарства. Порівнюючи податкову систему України та європейських країн, можна визначити, що принципової різниці у них немає. Особливість європейської системи оподаткування полягає в тому, що в ії̈ основу покладено переважно прогресивні шкали ставок оподаткування.

У Франції, яка має прогресивну податкову систему, існує нижня межа доходів, з яких не справляється податок, а у випадку їх перевищення поступово ставка податку збільшується, залежно від сум отриманого доходу, вище означеного рівня (табл. 1) [2]. 


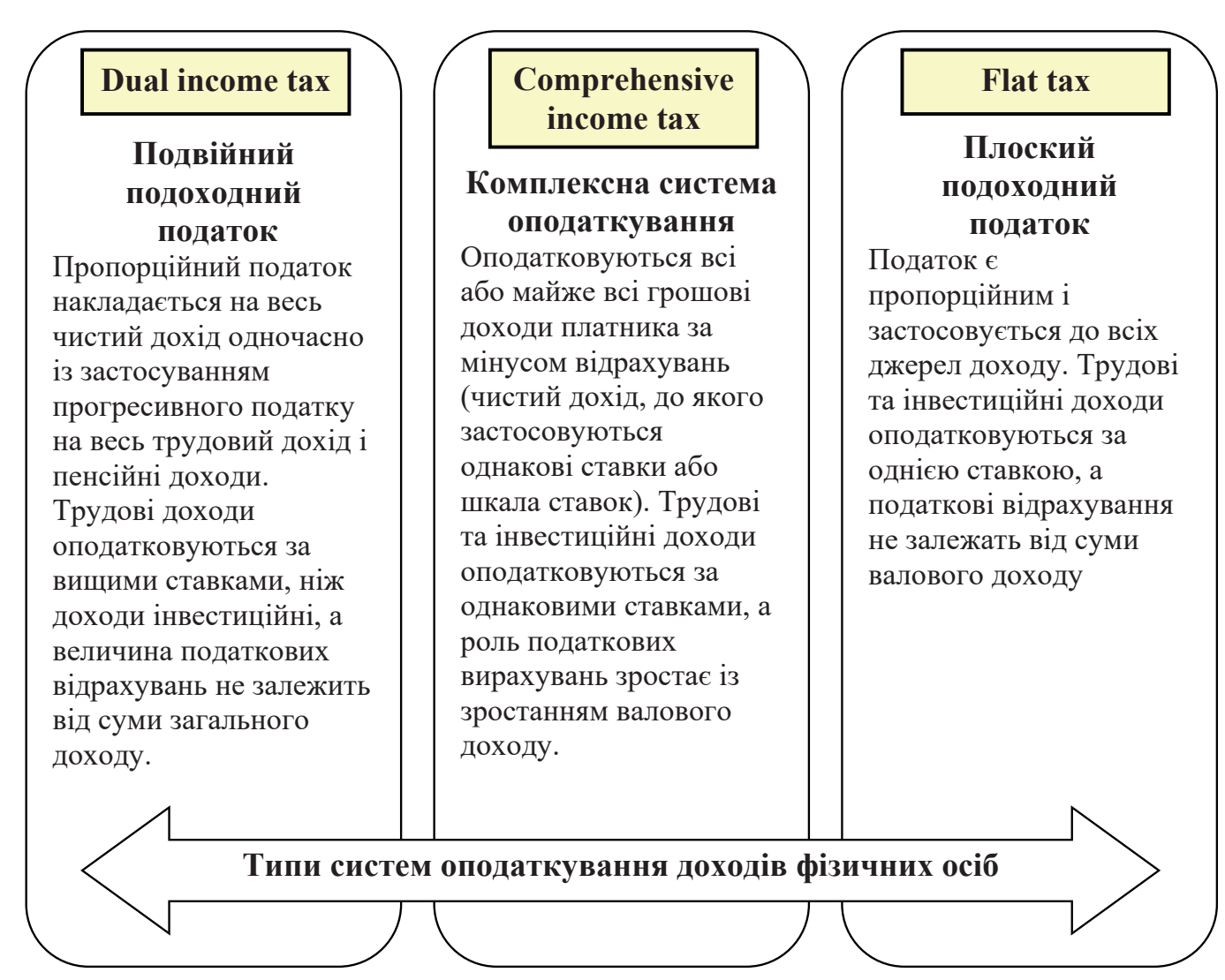

Рис. 1. Типологізація систем оподаткування доходів фрізичних осіб у зарубіжних країнах*

* Побудовано на основі [1].

Таблиця 1

Ставки податку на доходи фрізичних осіб у Франції за 2018 податковий рік*

\begin{tabular}{|c|c||}
\hline Оподатковуваний дохід, євро & Ставка податку, \% \\
\hline \hline До 9964 & 0,0 \\
\hline \hline $9965-27519$ & 14,0 \\
\hline \hline $27520-73779$ & 30,0 \\
\hline \hline $73780-156244$ & 41,0 \\
\hline \hline 156245 і більше & 45,0 \\
\hline
\end{tabular}

* Побудовано на основі [2, 3].

Особливістю адміністрування подоходного податку у Франції є оподаткування як доходів, котрі одержує платник всередині країни, так і тих, які отримано за ії межами.
При цьому платником $є$ не фрізична особа, а сім'я (якщо платник неодружений - сім'я 3 однієї особи) [3, с. 47-48]. 
Платникам подоходного податку присвоюють коефіцієнти:

Коефіцієнт 1 - самотнім особам без дітей; Коефріцієнт 2 - одруженим особам без дітей; Коесріцієнт 3 - подружжю з однією дитиною; Коефіцієнт 3,5 - подружжю з двома дітьми; Коефіцієнт 4 - подружжю з трьома дітьми.

Оподаткуванню підлягає сукупний дохід, який зазначається у податковій декларації. Загалом доходи платника поділяють на сім категорій: плата за роботу за наймом; доходи від оборотного капіталу (відсотки і дивіденди); доходи від торгівельної і промислової діяльності підприємств, які не $€$ акціонерними товариствами; доходи від надання в оренду землі та будівель; сільськогосподарські доходи; некомерційні доходи (доходи від вільних професій). До кожної з семи категорій застосовується окрема методика розрахунку, загальним правилом якої є утримання усіх витрат, які були понесені платником у процесі одержання таких доходів [4, с. 773].

у Німеччині податок встановлюється на всі види доходів, які отримує громадянин держави. При цьому всі платники при визначенні податку із заробітної плати поділяються на класи. Ставка податку в цій країні встановлюється в розмірі від 14\% до 53\%. У зв'язку зі складною демографрічною ситуацією в країні, з метою стимулювання народжуваності та зростання населення, неоподатковуваний мінімум для неодружених платників встановлюється на значно нижчому рівні, ніж для одружених. Податкові консультації податкоплатникам можуть надавати виключно податкові консультанти, уповноважені адвокати, аудитори, які відповідають за правильність нарахування податків [5].

У Швеції за кожним платником закріплюється реєстраційний номер, а також рахунок, на який перераховується податок. Резиденти зобов'язані сплачувати податок з усіх доходів, які вони отримують (підприємницька діяльність; капітал; заробітна плата). Податок обчислюється за прогресивною шкалою, загальна максимальна ставка становить 56,9\%.

У Норвегії резиденти сплачують національний і місцевий податок з усіх доходів, які були одержані в країні та за її межами. Податок на дохід фрізичних осіб з річної заробітної плати обчислюють за ставкою 9,5\%, якщо дохід - від 220501 до 248500 норвезьких крон [6, с. 932].

Однією із найбільш справедливих щодо платників подоходного податку з громадян вважається система його адміністрування у Великій Британії, де згаданий податок становить близько 65\% від усіх прямих податків, що надходять до бюджету країни. Особливістю оподаткування громадян $є$ те, що доходи поділяють на певні частки (шедули), які оподатковуються за окремою методикою. Ставка податку диференціюється залежно від річного доходу і становить: 20\%, 40\%, 50\%. Для визначення суми, що підлягає оподаткуванню подоходним податком з фактично одержаної суми доходів, вираховують податкову пільгу, яка для кожного громадянина визначається особисто (своєрідний неоподатковуваний мінімум). Окрім того, характерною рисою британської системи оподаткування $€$ застосування різних ставок податку до кожної окремої частини доходу, а платником податку є подружжя [7, с. 23].

В Іспанії декларація про доходи резидента включає всі доходи, які він одержав по всьому світу; незалежно від місця проживання його статус визначають на весь податковий період. Податок розраховується за ставкою від $24 \%$ до $45 \%$. Якщо річний дохід становить 300 тис. євро, то застосовується ставка $52 \%$.

На відміну від України, в Греції органам місцевого самоврядування надано доволі широке право в сфері податкової юрис- 
дикції. Так, наприклад, у країні особистий подоходний податок належить до місцевих, а ставки індивідуального подоходного податку застосовують в розмірі від 0\% до $40 \%$. Цікавим $є$ той факт, що сума річного доходу, яка не оподатковується зазначеним податком, становить 10 тис. євро, а на перевищення цієї суми податок стягується за прогресивною шкалою.

Податкову декларацію по подоходному податку подає в травні року, що йде за звітним, громадянин або його представник (консультант) в податковий орган за місцем проживання платника податків.

Законодавство Греції передбачає деякі пільги щодо індивідуального подоходного податку:

- 15\% витрат на оренду, якщо резидент в Греції проживає на орендованій квартирі, на загальну суму до 150 євро;

- витрати на страхування життя;

- 15\% витрат платника податків на власне навчання або на навчання дітей на приватних уроках;

- витрати на соціальне страхування;

- 15\% від загальної річної суми медичних витрат (відвідування лікаря і гос- піталізація), на суму, що не перевищує 6000 євро;

- 15\% від суми відсотків за кредитами на придбання нерухомості;

- витрати на придбання акцій грецьких компаній, вкладів до інвестиційних фондів;

- витрати на придбання комп'ютера [8].

У багатьох європейських країнах в системі оподаткування важливе місце посідає показник “граничний дохід”. Це - мінімальний розмір отриманого річного доходу, 3 якого сплачується податок (наприклад, для Франції це - 9965 євро, для Німеччини 9170 євро). При цьому розмір показника залежить від кількості дітей, сімейного стану платника та способу оподаткування за єдиною чи роздільною системою [3, с. 48].

Максимальні ставки податку на доходи фрізичних осіб в деяких країнах Європи наведено в табл. 2.

Подоходний податок з фізичних осіб є вагомим щодо обсягів надходжень до бюджету Італії. Його платниками виступають приватні особи - резиденти і нерезиденти, а об'єктом оподаткування - їх доходи. Цим податком оподатковуються всі доходи резидентів, отримані не тільки в Італії, а й за

Таблиця 2

Максимальні ставки податку на доходи громадян в країнах Європи*

\begin{tabular}{|c|c|c|c|c|}
\hline \multirow{2}{*}{ Країна } & \multicolumn{4}{|c|}{ Ставка, \% } \\
\hline & 2015 p. & 2016 p. & 2017 p. & 2018 p. \\
\hline Франція & 45 & 45 & 75 & 75 \\
\hline Данія & 51 & 55,4 & 55,6 & 55,8 \\
\hline Бельгія & 50 & 50 & 50 & 53,2 \\
\hline Португалія & 42 & 42 & 48 & 56 \\
\hline Іспанія & 45 & 45 & 45 & 43,5 \\
\hline Німеччина & 45 & 45 & 45 & 47,5 \\
\hline Норвегія & 27 & 25 & 39 & 39 \\
\hline Італія & 45 & 35 & 36 & 43 \\
\hline Люксембург & 42 & 34 & 29 & 42 \\
\hline
\end{tabular}

* Побудовано на основі [3, 9, 10]. 
її межами. Нерезиденти ж сплачують податок тільки з доходів, одержаних на території Італії [5]. Всі доходи платників поділяють на п'ять груп, залежно від джерел їх надходжень. До першої групи належать доходи, отримані від земельної власності, споруд і ведення сільськогосподарської діяльності. Другу групу становлять доходи від різних видів грошової ренти (відсотки за позиками, депозитними і поточними банківськими рахунками, облігаціями й іншими цінними паперами). В третій групі об'єднано усі трудові доходи, в тому числі і доходи осіб вільних професій. Четверта група складається 3 доходів від приватних комерційних підприємств. П'ята група об'єднує дохід від спекулятивного перепродажу землі, предметів мистецтва, нерухомості. Всі доходи, з кожної групи, оподатковуються окремо, відповідно до індивідуальної системи. Розрахунок податку провадиться за ставками, побудованими на принципі складної прогресії: шкала ставок коливається від 10 до 45\% [11].

У кожній країні існує специфрічний механізм адміністрування особистого подоходного податку з певними перевагами та недоліками. Водночас необхідно враховувати, що система податкового регулювання в розвинених країнах світу сформувалася відповідно до конкретних історичних та економічних особливостей, тому необхідно залучати у вітчизняну практику найбільш прийнятний до наших умов податковий інструментарій.

Європейські, а також американські податкові системи в царині оподаткування фрізичних осіб чітко дотримуються принципу соціальної справедливості - застосування прогресивних податкових ставок. У розвинутих країнах працівників, які мають невисокі заробітні плати, взагалі звільняють від сплати податку на доходи, а в Україні, навпаки, найбільший податковий тягар припадає саме на ці верстви населення [12].
Актуальним завданням сьогодні $є$ удосконалення пільгового оподаткування з податку на доходи фрізичних осіб. Прогресивна шкала оподаткування доходів фрізичних осіб дає можливість надавати податкові пільги не лише малозабезпеченим верствам населення, а й середньому класу. Пільгове оподаткування в європейських країнах має на меті підтримку малозабезпечених верств населення, середнього класу, індивідуального підприємництва, створення сім'ї, тобто націлене на суспільні цінності та норми [13, с. 108].

Українська система оподаткування надає платникам податку на доходи фрізичних осіб три види пільг:

1) невключення до складу загального місячного (річного) оподатковуваного доходу окремих видів доходів;

2) отримання податкової знижки;

3) отримання податкової соціальної пільги [5].

Проте державна політика у сфері особистого подоходного податку в Україні і надалі залишається неефективною. Для посилення ії̈ дієвості слід зробити все можливе, щоб підвищити відповідальність платників податку на доходи фрізичних осіб, зацікавити їх декларувати свої доходи та зміцнювати податкову й платіжну дисципліну, що є довготривалим процесом.

Як видно з наведених вище прикладів європейської практики, не існує однакового підходу до обчислення та сплати податку на доходи фрізичних осіб. У кожній країні механізм оподаткування визначають 3 урахуванням національних особливостей. Досвід економічно розвинених країн показує, що податковий тягар не має зменшувати економічну активність платника. Крім того, оподаткування не має перешкоджати внутрішній раціональній організації виробництва, його зовнішній орієнтації на попит споживачів. Основне правило побудови по- 
даткової системи з цією метою - ії прозорість і відкритість [14, с. 707].

Також слід констатувати, що суспільні трансформації, які мали місце в Україні, повною мірою не враховували і не використовували потенціал засобів податкової теорії та практики. Уряд має звернути увагу на зміну економічної ситуації у світовому масштабі, плануючи майбутню фріскальну політику в Україні в контексті оподаткування доходів громадян. Інформаційні системи, програмне забезпечення та технічна підтримка мають бути повноцінно впроваджені в систему електронного адміністрування податку на доходи фізичних осіб 3 урахуванням європейського досвіду та затримок у часі. Впровадження таких автоматизованих систем дасть змогу точніше прогнозувати та планувати показники бюджету, мінімізувати податкові ризики [15, с. 383].

Отже, за результатами дослідження європейського досвіду адміністрування подоходного податку з громадян можемо зробити висновок, що, порівняно з іншими країнами світу, система податкового адміністрування України не є досконалою, тому впровадження зарубіжного податкового досвіду сприятиме швидшому переходу до нової та дієвої системи оподаткування. Заслуговують на впровадження сегменти масово-роз'яснювальної роботи та налагодження партнерських взаємовідносин 3 платниками, комп'ютеризація та лібералізація процесів подання-приймання звітності. Це сприятиме досягненню ефективного результату і посиленню соціальної складової системи оподаткування.

Висновки. Прозорість і відкритість, спрямованість на вирішення соціальних питань та економічну мотивацію - платників податків $€$ основними правилами податкової системи європейських країн. В умовах створення в Україні соціально орієнтованої ринкової економіки, удосконалення механізмів оподаткування доходів фізичних осіб із урахуванням ефективного європейського досвіду $є$ пріоритетним завданням щодо вдосконалення української податкової системи.

Систематизація пріоритетів удосконалення процедур оподаткування доходів фрізичних осіб в Україні полягає в наступному. По-перше, необхідно переглянути ставки податку на доходи фрізичних осіб, зокрема, зменшити ставки податку стосовно соціально незахищених верств населення та запровадити помірну прогресивну шкалу. По-друге, важливо застосовувати досвід європейських країн в ракурсі використання логічно-обґрунтованого (вищого, ніж існує сьогодні в Україні) розміру неоподатковуваного мінімуму під час обчислення бази оподаткування. По-третє, існує нагальна потреба в спрощенні податкової звітності щодо податку на доходи фрізичних осіб, а головне - забезпеченні повноцінного фрункціонування електронного декларування доходів громадян. По-четверте, потребує перегляду й оптимізації пільгова політика в сфері адміністрування податку на доходи фрізичних осіб (диференціація джерел отримання доходів, врахування особливостей і соціального статусу фрізичної особи, надання пільг родинам з дітьми, незалежно від кількості неповнолітніх дітей тощо). По-п'яте, необхідно у перспективі реалізовувати ініціативи щодо добровільності та сумлінності декларування і сплати податку на доходи фрізичних осіб. Цьому сприятиме активність реалізації принципу соціальної справедливості в оподаткуванні, прозорий підхід у здійсненні розподільчо-регулюючої ффункції податку, розвиток податкової культури та податкової грамотності населення, імплементація європейського досвіду прогресивності в оподаткуванні доходів громадян, залучення до процесу подання декларацій про майновий стан і доходи фахівців та консультантів, в т. ч. на волонтерських засадах тощо. 


\section{Список використаних джерел}

1. Духновська Л. М., Пономаренко Р. А. Вплив ставки податку на доходи фрізичних осіб на доходи громадян України. URL : http://dspace. nuft.edu.ua/jspui/bitstream/123456789/17326/1/2. $\underline{p d f}$.

2. Tax rates in France for 2019. France Accountants - 2018. URL : https://www. franceaccountants.com/tax\#ourcharges 3.

3. Дутова Н.В., Лесік Є.С. Оподаткування доходів фрізичних осіб в Україні: проблеми та вдосконалення на базі досвіду зарубіжних країн. Економіка і організація управління. 2019. Вип. 1. C. 43-52.

4. Швець Ю. О., Бахметова Я. Ю. Оподаткування доходів фрізичних осіб: проблеми та перспективи в Україні та ЄС. Глобальні та національні проблеми економіки. 2017. № 17. С. $771-775$.

5. Танклевська Н. С. Світовий досвід оподаткування доходів фрізичних осіб. URL : https://www.pdaa.edu.ua/sites/default/files/ nppdaa/6.1/264.pdf.

6. Куба О. В., Горбенко Я. О. Оподаткування доходів фрізичних осіб: закордонний та вітчизняний досвід. Глобальні та національні проблеми економіки. 2018. Вип. 22. С. 931-935.

7. Крівцов О. О. Зарубіжний досвід оподаткування доходів фізичних осіб. Податкова політика. 2010. № 3(52). С. 18-28.

8. Міжнародний досвід: податкова система Греції. ДФС України. URL : http://sfs.gov.ua/arhiv/ modernizatsiya-dps-ukraini/arkchiv/mijnarodniydosvid-rozvitk/dosvid-modernizachii-krain-svity/ gresia/.

9. European CommissionTaxation and Customs Union. URL : https://ec.europa.eu/ taxation customs/.

10. Karpowicz A. Corporate income tax rates in the eu member states: Why lower means better. Financial Internet Quarterly "e-Finanse". 2018, Vol. 14, № 3. P. 32-48.
11. Податок на доходи фрізичних осіб в умовах інтеграції в європейське співтовариcmвo. URL : http://www.economyconfer.com.ual full article/971/.

12. Десятнюк О. М. Інновації податку на доходи фрізичних осіб у контексті норм Податкового кодексу України. Актуальні проблеми розвитку економіки регіону. 2012. T. 2. Вип. VIII. C. 3-9.

13. Абрамченко Н. А. Шляхи удосконалення пільгового оподаткування з податку на доходи фрізичних осіб. Науковий вісник Херсонського державного університету. 2016. Вип. 16. Ч. 3. C. 106-109.

14. Круковська О. В. Ключові зміни в рефоормуванні податкової системи України: реалії та перспективи. Мукачівський державний універcumem. 2016. № 2. C. 702-709.

15. Krysovatyi A., Lutsyk A., Synyutka N. Influence of time lags on the efficiency of fiscal policy in Ukraine. 9th International conference on advanced computer information technologies (ACIT), Ceske Budejovice, Czech Republic. 2019. P. 380-383.

\section{References}

1. Dukhnovska, L. M., Ponomarenko, R. A. Vplyv stavky podatku na dokhody fizychnykh osib na dokhody hromadian Ukrainy [Impact of the personal income tax rate on the income of Ukrainian citizens]. Available at: http://dspace.nuft.edu.ual jspui/bitstream/123456789/17326/1/2.pdf.

2. Tax rates in France for 2019. France Accountants - 2018. Available at: https://www. franceaccountants.com/tax\#ourcharges 3.

3. Dutova, N. V., Lesik, Ye. S. (2019). Opodatkuvannia dokhodiv fizychnykh osib v Ukraini: problemy ta vdoskonalennia na bazi dosvidu zarubizhnykh krain [Personal income taxation in Ukraine: problems and improvements based on the experience of foreign countries]. Ekonomika i orhanizatsiia upravlinnia - Economics and Management Organization, 1, 43-52 [in Ukrainian]. 


\section{АКТУАЛЬНІ ПИТАННЯ ТЕОРІЇ І ПРАКТИКИ ФІНАНСІВ}

4. Shvets, Yu. O., Bakhmetova, Ya. Iu. (2017). Opodatkuvannia dokhodiv fizychnykh osib: problemy ta perspektyvy $\vee$ Ukraini ta YeS [Personal income taxation: problems and prospects in Ukraine and the EU]. Hlobalni ta natsionalni problemy ekonomiky - Global and National Problems of Economy, 17, 771-775 [in Ukrainian].

5. Tanklevska, N. S. Svitovyi dosvid opodatkuvannia dokhodiv fizychnykh osib [World experience of taxing personal income]. Available at: https://www.pdaa.edu.ua/sites/default/files/nppdaa/6.1/264.pdf. [in Ukrainian].

6. Kuba, O. V., Horbenko, Ya. O. (2018). Opodatkuvannia dokhodiv fizychnykh osib: zakordonnyi ta vitchyznianyi dosvid [Personal income taxation: foreign and domestic experience]. Hlobalni ta natsionalni problemy ekonomiky - Global and National Problems of Economy, 22, 931-935 [in Ukrainian].

7. Krivtsov, O. O. (2010). Zarubizhnyi dosvid opodatkuvannia dokhodiv fizychnykh osib [Foreign experience in taxing personal income]. Podatkova polityka - Tax Policy, 3 (52), 18-28 [in Ukrainian].

8. Mizhnarodnyi dosvid: podatkova systema Hretsii [International experience: Greece's tax system.]. Available at: http://sfs.gov.ua/arhiv/modernizatsiya-dps-ukraini/arkchiv/mijnarodniy-dosvidrozvitk/dosvid-modernizachii-krain-svity/gresial [in Ukrainian].

9. European CommissionTaxation and Customs Union. Available at: https://ec.europa.eu/taxation customs/.

10. Karpowicz, A. (2018). Corporate income tax rates in the eu member states: Why lower means better. Financial Internet Quarterly "e-Finanse", 3, 32-48 (Vol. 14).
11. Podatok na dokhody fizychnykh osib $v$ umovakh intehratsii $v$ yevropeiske spivtovarystvo [Income tax on individuals in the context of integration into the European community]. Available at: http://www.economyconfer.com.ua/full article/971/.

12. Desiatniuk, O. M. (2012). Innovatsii podatku na dokhody fizychnykh osib u konteksti norm Podatkovoho kodeksu Ukrainy [Innovations of personal income tax in the context of the Tax Code of Ukraine.]. Aktualni problemy rozvytku ekonomiky rehionu - Current problems of economic development of the region, 2, 3-9 [in Ukrainian].

13. Abramchenko, N. A. (2016). Shliakhy udoskonalennia pilhovoho opodatkuvannia z podatku na dokhody fizychnykh osib [Ways to improve preferential taxation of personal income tax]. Naukovyi visnyk Khersonskoho derzhavnoho universytetu Scientific Bulletin of Kherson State University, 16, 106-109 [in Ukrainian].

14. Krukovska, O. V. (2016). Kliuchovi zminy $\checkmark$ reformuvanni podatkovoi systemy Ukrainy: realii ta perspektyvy [Key changes in reforming Ukraine's tax system: realities and prospects]. Mukachivskyi derzhavnyi universytet - Mukachevo State University, 2, 702-709 [in Ukrainian].

15. Krysovatyi, A., Lutsyk A., Synyutka N. (2019). Influence of time lags on the efficiency of fiscal policy in Ukraine. 9th International conference on advanced computer information technologies (ACIT), Ceske Budejovice, Czech Republic, 380-383 [in English].

Стаття надійшла до редакції 11.02.2020. 